FEDERAL RESERVE BANK OF SAN FRANCISCO

WORKING PAPER SERIES

\title{
Complexity of Global Banks and Their Foreign Operation in Hong Kong
}

\author{
Simon H. Kwan \\ Federal Reserve Bank of San Francisco \\ Kelvin Ho \\ Hong Kong Monetary Authority \\ Edward Tan \\ Hong Kong Monetary Authority
}

September 2019

Working Paper 2019-22

https://www.frbsf.org/economic-research/publications/working-papers/2019/22/

\section{Suggested citation:}

Kwan, Simon H., Kelvin Ho, Edward Tan. "Complexity of Global Banks and Their Foreign Operation in Hong Kong," Federal Reserve Bank of San Francisco Working Paper 2019-22. https://doi.org/10.24148/wp2019-22

The views in this paper are solely the responsibility of the authors and should not be interpreted as reflecting the views of the Federal Reserve Bank of San Francisco or the Board of Governors of the Federal Reserve System. 


\title{
Complexity of global banks and their foreign operation in Hong Kong ${ }^{1}$
}

\author{
Simon H. Kwan*, Federal Reserve Bank of San Francisco \\ Kelvin Ho, Hong Kong Monetary Authority \\ Edward Tan, Hong Kong Monetary Authority
}

September 2019

\begin{abstract}
This paper studies the relation between the complexity of global banking organizations and their foreign banking operations (FBOs) in Hong Kong. Our empirical evidence indicates that the complexity of the parent company has significant effects on their Hong Kong branch's business model, liquidity management, risk-taking, and profitability. The more complex the global banking organizations, their Hong Kong FBOs are more likely to derive a larger share of revenues from fee-based activities, and incur a higher cost of production despite enjoying a funding cost advantage. Notwithstanding the FBOs in Hong Kong may serve as a funding hub for its parent company, FBOs of more complex global banks tend to hold more liquid assets. While our empirical evidence suggests that the complexity of global banks has significant effects on FBOs risk-taking and profitability, the relation depends on how complexity is measured. For example, both the BCBS complexity score and the measure of geographic complexity are significant in explaining FBO profitability, but they have different signs. Likewise, geographic complexity and scope complexity are often found to have significantly different effects on FBOs performance. Taken together, the concept of global bank complexity has multiple dimensions, where different facets could have qualitatively different effects on FBOs in Hong Kong.

Keywords: Complexity, Global Banks, Foreign Banks

JEL codes: G21, F65
\end{abstract}

\footnotetext{
${ }^{1}$ Views in this paper are the authors only and do not necessarily represent the views of the Federal Reserve Bank of San Francisco, the Federal Reserve System, the Hong Kong Monetary Authority, or the Hong Kong Institute for Monetary Research. This paper was written when the first author visited the Hong Kong Institute for Monetary Research. Hospitality of the Institute and its staff is gratefully acknowledged.

*Corresponding author, simon.kwan@sf.frb.org
} 


\section{Introduction}

The complexity of global banking organizations has received heightened attention from both academia and policy makers, especially after the 2008 global financial crisis. The bankruptcy of Lehman Brothers and its aftermath prominently raised renewed concerns about not only "too big to fail" but also "too complex to resolve." Internationally, the Basel Committee on Banking Supervision (BCBS) recognizes the systemic effects of the failure of a large financial institution on the broader financial system. The reform of the international bank capital standard, Basel III, requires additional loss absorbency from global systemically important banks (G-SIBs) over and above the requirements for all internationally active banks, and the assessment of the additional loss absorbency is in part determined by the G-SIB's complexity. In addition to imposing higher loss absorbency capital for more complex G-SIBs, banking regulators around the world also require large and complex banking organizations to submit a recovery and resolution plan periodically. ${ }^{2}$ The primary objective of resolution planning is to provide the resolution authority a detailed roadmap to resolve the G-SIB orderly within a reasonable timeframe in the event of failure. It clearly would not be necessary were G-SIBs not overly complex.

While researchers in banking are advancing the knowledge related to the complexity of global banking organizations in recent years, a long-time question about the management and performance of an affiliate within an organization has led to many theories and research papers in corporate finance since Coase (1937) seminal work. At issue is how affiliates of complex organizations are expected to be managed, and does the stand-alone performance of an affiliate matter in the overall organization? In other words, would it be meaningful to view an affiliate of a complex organization independently?

Almost all corporate finance papers approach the theory of the firm from a top-down view; for example, how does a conglomerate organize itself, allocate scarce resources internally, or choose the portfolio of business lines. In this paper, we take a very different approach: using a unique dataset, we examine the characteristics, performance, and risk-taking of foreign banking offices in Hong Kong (FBOs) that are affiliates of global banking organizations. A priori, different global banking organizations have different business models, strategies, organization structure, and management style. Banking markets around the world are very different, in terms of market concentration, permissible activities, supervision and regulation. Some global banks are headquartered in countries with well-developed capital markets (e.g., the U.S.A.) while others are in more bank-centric economies (e.g., the euro area). Hence, it would seem unlikely that two affiliates of two different complex banking organizations share similar characteristics. It would seem even more unlikely that their commonalities may be related to their parent organizations' complexity.

On the other hand, one thing in common among foreign banks in Hong Kong is the very fact that they are all located in Hong Kong, facing the same local banking market and subject to the same supervision and regulation by the Hong Kong Monetary Authority. As an international financial center, Hong Kong has a large number of foreign banking operations, totaling 146 in 2017. A large majority of these foreign banking affiliates were established as branches of foreign banks. In 2017, 45 of the top 50 global banking organizations (by total assets) have established an affiliate in Hong Kong. These foreign banking

\footnotetext{
${ }^{2}$ In the U.S., the Dodd-Frank Wall Street Reform and Consumer Protection Act devoted both Title I and Title II to address the failure and resolution of systemically important financial institutions (SIFIs). Among other provisions, the Dodd-Frank Act requires SIFls to provide a resolution plan, or the so-called living will, to its regulators for approval annually.
} 
operations (FBOs) vary by size and scope of activities. For example, at one end of the spectrum, some foreign banks are active in both funding and lending activities in Hong Kong, gathering local deposits to provide loans to local borrowers. At the other end of the spectrum, some foreign banks provide little to no banking services and products to local customers while mainly servicing their home country customers doing business in Hong Kong. Whether complex global banks' foreign operations in Hong Kong share any similar characteristics, and if so, how these characteristics are related to their parent organizations' complexity are empirical questions.

Global banks' FBOs in Hong Kong provide a unique setting to test these hypotheses. Uncovering the empirical regularities of foreign banking organizations in Hong Kong could shed light on the theory of the firm, as well as providing policy implications for the country or jurisdiction hosting these foreign banking organizations. Since many FBOs' parents are G-SIBs, an important question for the banking supervisors in Hong Kong is whether G-SIBs' FBO in Hong Kong, either individually or collectively, adds another layer of systemic risk to its financial system. If so, can this marginal contribution be related to the parent G-SIBs' complexity?

Since there is no readily available or consensus measure of banking organization complexity, in this paper, we measure global banks complexity using three approaches: First is the concept pioneered by Cetorelli and Goldberg $(2014)$, who proposed three metrics to measure global bank complexity, namely, organizational complexity, business complexity, and geographic complexity. Second is the complexity score computed by the Basel Committee on Banking Supervision to assess the G-SIB additional loss absorbency capital requirement. Third is to appeal to the concept of opacity in the banking literature by arguing that complex banking organizations also are more opaque.

Our empirical evidence suggests that the complexity of global banking organizations has significant effects on their Hong Kong branch's business activities, liquidity management, risk-taking, and profitability. Since we motivate our measures of global banks complexity from several different perspectives, different complexity measures are found to have different effects on FBOs, suggesting that the concept of complexity has multiple dimensions.

The rest of the paper is organized as the followings: Section II briefly reviews what corporate finance theory says about the performance of bank affiliates that are part of a global banking organization, as well as the recent literature on bank complexity. Section III discusses the empirical measures of global banking organization's complexity, followed by the methodology to test the relation between global bank complexity and the FBOs in Hong Kong. Data and descriptive statistics are provided in Section IV. Section V presents the empirical results. Section VI concludes.

\section{Related Literature}

This paper is related to two strands of literature. First is the theory of the firm, which has been around for a long time and has a well established literature. Second is the complexity of global banking organizations, which is quite new but has recently received a lot of attention, following the global financial crisis that was precipitated by many large financial institutions getting into trouble.

Coase (1937) raised a fundamental question about the theory of the firm: how decisions taken inside a hierarchy differ from those taken in the marketplace? Coase suggested that decisions within a hierarchy are determined by power considerations rather than relative prices. Lamont (1997) and Shin and Stulz (1998) found evidence that resource allocation in diversified firms differs from that of nondiversified firms in the same industries. The misallocation of resources was found to have explanatory power for 
the valuation discount in diversified firms relative to a portfolio of nondiversified firms in the same industries [Land and Stuliz (1994), Berger and Ofek (1995), Lins and Servaes (1999), Scharfstein and Stein (2000)]. Theories to explain the diversification discount include agency theories [e.g., Shleifer and Vishny (1989) and Rajan, Servaes, and Zingales (2000)], influence cost models (Meyer, Milgrom, and Roberts (1992), and intra-organization equity model [(Adams (1965) and Homans (1974)].

At the opposite end of the spectrum, Williamson (1975) argues the benefits of diversification. To the extent that there is friction in external capital markets, internally generated funds in diversified firms can be pooled and allocated to the best opportunities efficiently. Papers that found evidence of efficient internal capital market include Li and Li (1996), Matsusaka and Nanda (1997), and Stein (1997).

In banking, while there is a large body of literature on the economies of scope in financial conglomerates, the empirical evidence as a whole seems inconclusive [for example, Berger, Hanweck, and Humphrey (1987), Berger and Humphrey (1991), Ferrier, Grosskopf, Hayes, and Yaisawarng (1993)]. Approaching scope economies indirectly, Houston, James, and Marcus (1997) found bank holding companies allocate funds efficiently to bank subsidiaries facing more favorable lending opportunities, whereas Laeven and Levine (2007) found evidence of diversification discount in financial conglomerates. ${ }^{3}$ Of interest to this paper is whether complex banking organizations are more likely to diversify away from financial intermediation activities into fee-based activities.

While the concept of complexity and scope economies are related in the context of organizational structure, in banking, the complexity of banking organizations also could lead to externalities that result in distortions. They include the moral hazard issues when a banking organization is perceived as toocomplex-to-resolve, and financial stability implications when a complex banking organization poses systemic risk to the financial system. On the too-complex-to-resolve in banking, its twin moral hazard problem of too-big-to-fail has a large body of literature before the global financial crisis. ${ }^{4}$ Since the financial crisis, the literature shifted to focus on the systemic implications of large and complex banking organizations, and the effectiveness of post-crisis reform in limiting the moral hazard problem. ${ }^{5}$

Given the implications of complex banking organizations on the financial system, banking researchers squarely seek to understand their characteristics and evolution [Cetorelli, McAndrews and Traina (2014)], as well as metrics to measure global bank complexity [Cetorelli and Goldberg (2014)]. Berger, El Ghoul, Guedhami and Roman (2017) found a positive relationship between internationalization and bank risk-taking among banking firms in the U.S. Closely related to this paper, Cetorelli and Goldberg (2016) found that the more complex the banking group, the lower is the lending sensitivity of their foreign bank branches to funding shocks in the US.

\section{Methodology}

To study the relation between the complexity of global banks and their foreign operation in Hong Kong, we need empirical measures of global banks' complexity. In this paper, we measure the complexity of global banking organizations using three approaches. First, Cetorelli and Goldberg (2014) proposed to measure global bank complexity along three dimensions: organizational complexity, business complexity, and geographic complexity. Organizational complexity measures the number of majority-

\footnotetext{
${ }^{3}$ Leaven and Levine (2007) found that more diversified banking organizations tend to have a higher share of nonfinancial income, as well as more stable revenues and net income.

${ }^{4}$ See for example, Stern and Feldman (2009) for a review of the literature.

${ }^{5}$ Please see Ueda and Di Mauro (2013), Balasubramnian and Cyree (2014), Kelly, Lustig and Van Nieuwerburgh (2016), Acharya, Anginer and Warburton (2016), and Cetorelli and Traina (2018).
} 
owned affiliates under the parent company. Business complexity measures the number of distinct business lines across the entire organization. Geographic complexity measures the number of distinct geographic regions where the global bank has economic presence. Following Cetorelli and Goldberg, we obtain data from S\&P Capital IQ to construct the following two measures of complexity: ${ }^{6}$

Business Complexity $=\frac{T}{T-1}\left(1-\sum_{\tau=1}^{T}\left(\frac{\text { revenue }_{\tau}}{\text { total revenue }}\right)^{2}\right)$

The normalized Herfindahl index has a value between zero and one, with a higher index value reflects a higher degree of business complexity. It is based on the number of distinct business types, $\tau$, from which the global banking organization generates revenue in a given year, where business types are according to the North American Industry Classification System (NAICS). ${ }^{7}$

Geographic Complexity = $1-($ domestic revenue $/$ total revenue $)$,

where domestic revenue includes revenues from the global bank's home country.

Following Cetorelli and Fritz [CGFS (2018)], we construct:

Scope complexity $=\sum_{\tau=1}^{T}\left(\right.$ distance $_{\tau} \times$ revenue $\left._{\tau}\right) /$ total revenue, where $\tau$ is the distinct business type from which the global banking organization generates revenue in a given year according to the NAICS, and distance has a value of 1 to 5 according to the NAICS's proximity to commercial banking (5221). ${ }^{8}$ Scope complexity measures the contributions of non-traditional banking revenues to the global banking organization's total revenues, weighted by the distance to commercial banking. ${ }^{9}$

Our second approach to measure global bank complexity is to follow the BCBS framework. Specifically, to assess the systemic importance of global banking organizations and the risks these organizations pose to the larger financial system, the BCBS developed a framework to determine the higher (additional) loss absorbency requirement for G-SIBs. This framework compares a global bank's activity over twelve indicators, which are grouped into five categories of systemic importance: (1) Size, (2) Interconnectedness, (3) Substitutability/financial institution infrastructure, (4) Complexity, and (5) Crossjurisdictional activity. Under this framework, the 'Complexity' category is measured by three indicators: (i) Notional amount of OTC derivatives, (ii) Trading and available-for-sale securities, and (iii) Level 3 assets. The BCBS publishes global banks' complexity score annually since the inception of this framework.

\footnotetext{
${ }^{6}$ Cetorelli and Goldberg (2014) obtained data from Bureau van Dijk Bankscope to construct their complexity measures, whereas our source does not have data on affiliate count.

${ }^{7}$ Commercial banking has a NAICS code of 522. Other business types are defined according to 3-digit NAICS codes for financial industries and 2-digit NAICS codes for all other industries.

8 Specifically, business type with NAICS equals to 522 has a value of one for distance, distance for a segment with NAICS started with $524=2$, distance for a segment started with $51=3$, and distance for a segment started with $8=$ 4.

${ }^{9}$ A global bank that engages solely in commercial banking activities has a scope complexity equals 1 , whereas an organization that engages solely in nonfinancial activities has a scope complexity of 5 .
} 
Complexity = complexity score published by BCBS in assessing G-SIBs additional loss absorbency requirement.

In the third approach to measure global bank complexity, we argue that complexity in banking is the primary source of opacity in banking organizations. As such, we appeal to the literature on bank opacity and use the opacity measures developed in that literature as a proxy for bank complexity. Specifically, Morgan (2002) found that bonds issued by banks and insurance companies were more likely to have split bond ratings by the two major credit rating agencies, a reflection of financial intermediaries inherent opaqueness that led to credit rating disagreement. Following Morgan, we measure complexity of global banking organizations by the incidence of split bond rating, and the degree of rating disagreement.

Rating split frequency $=\sum_{j=1}^{J} s \operatorname{slit}_{j} / J$

where split $_{j}=1$ if debt security tranche $j$ has split bond rating, and zero otherwise, and $J$ is the number of debt security tranches issued by the global banking organization that are rated by more than one credit rating agency ${ }^{10}$.

Average rating split distance $=\sum_{j=1}^{J}$ rate_distance $_{j} / J$ where rate_distance $_{j}=\mid$ rating $_{j, k}-$ rating $_{j, l} \mid$ for a debt security tranche $j$ rated by credit rating agency $k$ and $l^{11}$, and $J$ is the number of debt security tranches issued by the global banking organization that are rated by more than one credit rating agency.

In Flannery, Kwan, and Nimalendran (FKN) $(2004,2013)$, outside analysts' earnings forecasts were used to construct an independent measure of a banking firm's opacity. Ceteris paribus, larger analyst forecast errors or greater disagreement across analysts' indicates that the firm is more complex and difficult to evaluate or understand. ${ }^{12}$ We define:

Forecast error $=\frac{\left(\left|\operatorname{median}\left(e p s_{-1}^{f}\right)-e p s^{a}\right|+\left|\operatorname{median}\left(e p s_{-4}^{f}\right)-e p s^{a}\right|+\left|\operatorname{median}\left(e p s_{-7}^{f}\right)-e p s^{a}\right|+\left|\operatorname{median}\left(e p s_{-10}^{f}\right)-e p s^{a}\right|\right) / 4}{\text { price }}$ where $e p s_{-m}^{f}$ is the median forecast of earnings per share (EPS) m-month prior to earnings announcement date, $\operatorname{eps}^{a}$ is the actual EPS, and price is the year-end stock price.

Forecast dispersion $=\frac{\left(\mathrm{SD}\left(e p s_{-1}^{f}\right)+\mathrm{SD}\left(e p s_{-4}^{f}\right)+\mathrm{SD}\left(e p s_{-7}^{f}\right)+\mathrm{SD}\left(e p s_{-10}^{f}\right)\right) / 4}{\text { price }}$

where $\mathrm{SD}\left(\right.$ eps $\left._{-m}^{f}\right)$ is the standard deviation of forecasts $\mathrm{m}$-month prior to earnings announcement date, eps ${ }^{a}$ is the actual EPS, and price is the year-end stock price.

\footnotetext{
${ }^{10}$ Debt security tranches that are unrated or rated by only one credit rating agency are excluded.

${ }^{11}$ To calculate rate_distance, the credit ratings of different credit rating agencies are first mapped onto a common numeric scale ranging 0-20, with 20 indicating the highest credit quality. For details of the mapping scale, please see Appendix 1. If a debt security is rated by more than two credit rating agencies, the maximum rate_distance would be used.

${ }^{12}$ Their results based on the analysts' earnings forecast were mixed, along with their results on market microstructure properties, leading FKN (2004) to conclude that banking firms were not more opaque than nonbanking firms. However, during the $2008-09$ global financial crisis, FKN (2013) found that banking firms' opacity rose significantly.
} 
In sum, our eight measures of global bank complexity are derived from three different frameworks, two have the flavor of a bottom-up approach and the third resembles a top-down view. Without taking a stand on the preference of the measures, we would like to emphasize that the concept of global bank complexity has multiple dimensions. In Section IV, we provide pairwise correlations of the eight complexity measures.

We then turn to the characteristics of the FBOs in Hong Kong that are of interest for this study. In addition to being guided by the literature, concerns about safety and soundness, as well as financial stability motivate the choice of the dependent variables. In this paper, we examine the relation between the complexity of global banking organizations and their FBO's business model, risk-taking, liquidity management, profitability, and efficiency.

To study FBOs' business model in Hong Kong, we examine their major revenue sources, cost efficiency, portfolio composition, and funding mix. The ratio of noninterest income to total income measures the share of fee-based activities contributing to total revenues. The ratio of total loans to total assets measures the degree of credit intermediation provided by the $\mathrm{FBO} .{ }^{13}$ Cost efficiency is measured by the ratio of operating cost to total income, and is expected to be determined by the underlying production function of the chosen product mix and input factors. ${ }^{14}$ Funding cost, averaging over the last four quarters, is computed as the weighted average of interest expenses to total liabilities for Hong Kong dollar and US dollar denominated liabilities. ${ }^{15}$ The deposit-to-asset ratio, and the wholesale deposit-toasset ratio measure funding mix.

Noninterest income to total income $=$ non-interest income $/$ total income .

Total loans to total assets $=$ total loans and advances $/$ total assets.

Operating cost to total income $=$ operating expenses $/$ total income where operating expenses $=$ staff and rental expenses + other expenses.

4Q Average funding cost $=\sum_{q=1}^{4}$ funding $\operatorname{cost}_{q} / 4$

where $q$ denotes the quarter in the year.

Deposits to assets $=$ total deposits from customers / total assets.

Wholesale deposits to assets $=$ due to banks $/$ total assets.

FBOs' liquidity management in Hong Kong is of particular interest to the host country from two perspectives. Following Kwan, Hui, and Wong (2019) who found evidence of transmission of liquidity shocks from the home country to the host country, we delve deeper into whether and how the complexity of the global banking organizations may be systematically related to their FBO liquidity management in Hong Kong. Second, FBOs' activities in the interbank loan market could shed light on

\footnotetext{
${ }^{13}$ Replacing total loans by real estate loans provides qualitatively similar results.

${ }^{14}$ Although cost efficiency may also include the X-efficiency (or the deviation from the cost efficient frontier), it seems likely to be of second order importance in the magnitude of cost efficiency.

${ }^{15}$ Funding cost here refers to the weighted average of Hong Kong dollar funding cost and US dollar funding cost. Funding denominated in these two currencies accounts for nearly $90 \%$ of the total liabilities at the end of 2017.
} 
their interconnectedness with other financial institutions in Hong Kong, as well as their potential spillover to the host country financial system. This is of particular interest to host country policy makers when the parent company is both complex and systemic importance. To capture liquidity management, we use the liquid asset-to-total asset ratio, net-due-from overseas office-to-asset ratio, and liquid assetto-runnable debt ratio. To measure interbank activities, we examine the ratio of net interbank lendingto-total asset.

Liquid assets to assets $=$ liquid assets $/$ total assets

where liquid assets $=$ cash + due from Exchange Fund + government bills, notes and bonds.

Net due from overseas offices to assets = net due from overseas offices / total assets where net due from overseas offices = due from overseas offices - due to overseas offices.

Liquid assets to runnable debts = liquid assets / runnable debts

where runnable debts = demand deposits and current accounts + savings deposits + time, call and notice deposits (repayable or callable within 7 days) + amount payable under repos + due to banks.

Net interbank lending to assets = net interbank lending / total assets where net interbank lending = (due from banks - due from connected Als in Hong Kong - due from overseas offices) - (due to banks - due to connected Als in Hong Kong - due to overseas office).

(Credit) Risk-taking is measured separately by the amount of classified loans, net-charge-offs, and loanloss-provisions, after being deflated by total loans outstanding. Profitability is measured by the level of return-on-assets, as well as its volatility over last eight quarters

Classified loan ratio $=$ classified loans $/$ total loans and advances.

Net charge off ratio $=$ net charge-off $/$ total loans and advances.

ROA = operating profit before tax / average assets.

8Q SD $($ ROA $)=$ standard deviation of $R O A$ in the trailing 8 quarters.

Table 1 summarizes the construction of the above variables. We collect foreign branch level data from their regulatory filings with the Hong Kong Monetary Authority to construct the above 14 financial variables. For each of the above dependent variables, we run pooled time-series cross section multivariate weighted least square regressions with the eight complexity measures as explanatory variables and time fixed-effect using total assets as weights. ${ }^{16}$ Moreover, we control for home country banking regulation, relative to Hong Kong, using the Bank Activity Regulatory Index in Barth, Caprio, and Levine (2013) since research has found effects of regulatory differences on global banks' foreign operations [Houston, Lin and Ma (2012)]. ${ }^{17}$ Specifically,

\footnotetext{
${ }^{16}$ Scatter plots indicate some outliers from small FBOs. Ordinary least square regressions provide qualitatively similar results.

${ }^{17}$ Higher values of Regulatory tightness $s_{i t}$ indicate more stringent banking regulations in the home country of foreign banks relative to that in Hong Kong.
} 


$$
\begin{aligned}
& Y_{i t}=\alpha+\beta_{1} \text { Complexity }_{i t}+\beta_{2} \text { Business Complexity }_{i t}+\beta_{3} \text { Geographic Complexity }_{i t} \\
&+\beta_{4} \text { Scope Complexity }_{i t}+\beta_{5} \text { Rating split frequency }_{i t} \\
&+\beta_{6} \text { Average rating split distance }_{i t}+\beta_{7} \text { Forecast error }_{i t} \\
&+\beta_{8} \text { Forecast dispersion }_{i t}+\beta_{9} \text { Regulatory tightness }_{i t} \\
&+ \text { time fixed effects }+e_{i t}
\end{aligned}
$$

where $Y_{i t}$ is one of the 14 financial variables.

Note that the eight complexity measures on the right-hand-side of (1) capture different dimensions of global banks' complexity. The estimated coefficients are the partial effects of the parent company's complexity (on a given dimension) on the FBO's financial ratio.

\section{Data}

We obtain data from the following sources to construct the complexity measures for global banking organizations: The complexity scores under the BCBS framework to determine additional loss absorbency requirement for G-SIBs are from the BIS. Micro data to construct global bank complexity, including business line complexity, geographic complexity, and scope complexity are from the Standard and Poor's Capital IQ. Both bond rating data and analysts' earnings forecast data for global banking organizations are from Bloomberg.

We obtain branch level data of global banks' Hong Kong operation from their regulatory reports filed with the Hong Kong Monetary Authority. Our sampling period is from 2013 to 2017, during which the BCBS complexity score is available. Of the 131 global banking organizations that engage in banking activities in Hong Kong, 13 have subsidiaries while 127 choose to open branch(es) in Hong Kong. ${ }^{18}$ In this paper, only branches of global banks are included in the analysis due to the followings: (1) subsidiaries of foreign banks tend to be much larger and more independent from their parent companies; (2) since subsidiaries of foreign banks are supervised like local banks that are headquartered in Hong Kong, the supervisory implications from our analysis would be muddled by their inclusion; ${ }^{19}$ and (3) nonparametric tests reject the hypotheses that the financial variables (in section III) are similar between subsidiaries and branches of foreign banking organizations. ${ }^{20}$

Our final sample includes 57 complex global banking organizations that have branch(es) in Hong Kong from 2013 to 2017. When a global banking organization has more than one branch in Hong Kong, its Hong Kong branches are synthetically merged into a single entity to provide a one-to-one relation between the parent company and the Hong Kong branch. To control for the effects of a branch network versus a single branch, we include a branch dummy variable which equals one if the global bank has multiple branches in Hong Kong, zero otherwise. Descriptive statistics for the final sample are provided in Table 2: panel A shows the summary statistics of the 8 complexity measures of the global banking

\footnotetext{
${ }^{18}$ Some global banking organizations have operations both in the form of subsidiaries and branches in Hong Kong. ${ }^{19}$ One of the objectives of this paper is to study the effects of foreign banks on the safety and soundness of the host country's banking system, as well as its financial stability. This would argue against including subsidiaries of foreign banks when these subsidiaries are already supervised like local banks.

${ }^{20}$ Results of the nonparametric tests are available upon request.
} 
organizations; panel B shows the summary statistics of the 14 financial variables of the global banks' foreign branch in Hong Kong.

Table 3 provides the pairwise correlation of the eight complexity measures of the global banking organizations in our sample. While some correlations are statistically significant, the strength of the correlation is uneven. Note that when the complexity measures are derived from different frameworks, the correlations are weaker, suggesting that the different measures capture different dimensions of complexity of the banking organizations.

\section{Empirical Findings}

Table 4 provides the WLS regression results of estimating equation (1) for the six variables related to FBOs business models. Column (1) reports the effects of the parent company's complexity on FBOs' noninterest income-to-total income ratio: Of the four complexity measures, two have significantly positive coefficients. The findings indicate that the more complex global banking organizations' FBO in Hong Kong tend to have a higher share of fee-based, noninterest revenue source. Three of the four opacity measures are also significantly positive, providing further evidence that more opaque global banks tend to engage in more fee-based activities in Hong Kong. Despite the fact that by construction, the eight explanatory variables capture different dimensions of complexity and opacity, they have a fairly consistent effect on FBOs' revenue mix. ${ }^{21}$ In column (2), two complexity measures and two opacity measures are found to have significantly positive effects on FBOs' cost to income ratio. To the extent that fee-based noninterest revenues are more costly (labor intensive) to produce, the results point to qualitatively different business models among FBOs from complex (and opaque) parent organizations. In column (3), although the effects of parent company's complexity on FBOs' loan-toasset ratio appear to be mixed, the significantly negative relation between Scope complexity and loan concentration is internally consistent. The significantly negative relation between more opaque banks and less loan concentration suggests that non-lending activities are more opaque than loans on average. In columns (4) and (5), more complex global banks tend to rely more on retail deposits and less wholesale deposits, which are also consistent with their lower funding costs (column (6).

Table 5 provides the WLS regression results for the FBOs liquidity management. In column (1), while the four complexity measures are insignificant, there is some evidence that more opaque global banks use their Hong Kong FBOs as a funding hub for their parent companies, as evidenced by the two significantly positive coefficients on opacity. In columns (2) and (3), FBOs of global banks with higher complexity score and more geographic complexity are found to hold more liquid assets, as a share of total assets [column (2)] and relative to the amount of runnable debt [column (3)]. The significantly negative coefficients of scope complexity on liquid assets suggest that FBOs of global banks with a smaller product mix hold less liquid assets, perhaps out of less precautionary demand for liquidity buffer. On balance, the findings suggest that FBOs of more complex global parents do not seem to be particularly more vulnerable to liquidity shocks due to their higher liquid asset buffer. Regarding interbank lending in column (4), FBOs of global banks with higher complexity score and scope complexity tend to engage in more interbank lending, whereas business complexity has a significantly negative coefficient. Once

\footnotetext{
${ }^{21}$ One exception is the Forecast dispersion, whose coefficient often exhibits opposite sign to that of Forecast error.
} 
again, complexity has multiple dimensions which could have qualitatively different effects on FBOs liquidity management.

Table 6 provides the WLS regression results for the five variables on FBOs risk taking and profitability. In column (1), classified-loan-ratio is significantly positively related to business complexity and geographic complexity, while negatively related to scope complexity. In column (2), scope complexity is also significantly negative in explaining the net-charge-off-ratio. The findings suggest that global banks offering a wider product mix take less credit risk, whereas global banks that have more complex business lines and geographic coverage take more credit risk. In columns (3) and (4), global banks with higher complexity score tend to have lower profitability and higher earnings volatility; and global banks with more geographic coverage tend to be more profitable. FBOs of more opaque global banks are found to exhibit lower profitability and higher earnings volatility.

\section{Conclusions}

In this paper, we study the relation between the complexity of global banking organizations and their FBOs in Hong Kong. We found evidence that the complexity of the parent company has significant effects on their Hong Kong branch's business model, liquidity management, risk-taking, and profitability. The more complex the global banking organizations, their Hong Kong FBOs are more likely to derive a larger share of revenues from fee-based activities, and incur a higher cost of production despite enjoying a funding cost advantage. While more opaque global banks are more likely to upstream funds from their FBOs in Hong Kong to the holding company, FBOs of complex parents tend to hold more liquid assets. Despite the systemic importance of their parent companies, FBOs of complex banking organizations could mitigate liquidity concerns of host country regulators by their higher liquidity buffer.

While our empirical evidence suggests that the complexity of global banks has significant effects on FBOs risk-taking and profitability, the relation depends on how complexity is measured. For example, both the BCBS complexity score and the measure of geographic complexity are significant in explaining FBO profitability, but they have different signs. Likewise, geographic complexity and scope complexity are often found to have significantly different effects on FBOs performance. Taken together, the concept of global bank complexity has multiple dimensions, where different facets could have qualitatively different effects on FBOs in Hong Kong. 


\section{References}

Acharya V., Anginer D., and Warburton J., (2016), "The end of market discipline? Investor expectations of Implicit Government Guarantees”, https://ssrn.com/abstract=1961656.

Balasubramnian B., and Cyree K., (2014), "Has market discipline on banks improved after the DoddFrank Act?" Journal of Banking and Finance, 41, 155-166.

Bank for International Settlements Committee on the Global Financial System, 2018, Structural Changes in Banking after the Crisis, CGFS Papers No 60.

Barth, James R., Caprio, Gerard, Jr., and Ross Levine (2013), "Bank Regulation and Supervision in 180 Countries from 1999 to 2011." National Bureau of Economic Research Working Paper 18733.

Berger A., El Ghoul S., Guedhami O., and Roman R., (2017), "Internationalization and Bank Risk", Management Science, 63(7): 2283-2301.

Berger A., G. Hanweck, and D. Humphrey (1987), "Competitive viability in banking: scale, scope, and product mix economies," Journal of Monetary Economics, 20: 501-520.

Berger A., and D. Humphrey (1991), "The dominance of inefficiencies over scale and product mix economies in banking," Journal of Monetary Economics, 28: 117-148.

Carmassi J., and Herring R., (2016), "The corporate complexity of global systemically important banks", Journal of Financial Services Research, 49: 175-201.

Ceterolli N., and Goldberg L., (2014), "Measures of global bank complexity", Federal Reserve Bank of New York Economic Policy Review, Pages 107-126.

Ceterolli N., and Goldberg L., (2016), “Organizational complexity and balance sheet management in global banks", NBER Working Paper.

Cetorelli, N., J. McAndrews, and J. Traina (2014), "Evolution in bank complexity," Federal Reserve Bank of New York Economic Policy Review (Dec), 85-106.

Ceterolli N., and J. Traina (2018), "Resolving too big to fail," Federal Reserve Bank of New York Staff Report No. 859.

Coase R.H., (1937), "The nature of the firm", Economia, 4(16): 386-405.

Ferrier G., S. Grosskopf, K. Hayes, and S. Yaisawarng (1993), "Economies of diversification in the banking industry: a frontier approach,” Journal of Monetary Economics, 31: 229-249.

Flannery M., Kwan S., and Nimalendran M., (2004), "Market evidence on the opaqueness of banking firms' assets", Journal of Financial Economics, 71(3): 419-460.

Flannery M., Kwan S., and Nimalendran M., (2013), “The 2007-2009 financial crisis and bank opaqueness", Journal of Financial Intermediation, 22(1): 55-84.

Kelly, B., H. Lustig, and S. Van Nieuwerburgh (2016), "Too-systemic-to-fail: What option markets imply about sector-wide government guarantees," American Economic Review 106 (6), 1278-1319. 
Kwan S., Wong E., and Hui C., (2019)," The International Transmission of Shocks through the Lens of Foreign Banks in Hong Kong," FRBSF WP No.2014-25.

Laeven L., and Levine R., (2007), "Is there a diversification discount in financial conglomerates?" Journal of Financial Economies, 85(2): 331-367.

Morgan D., (2002), "Rating banks: risk and uncertainty in an opaque industry", American Economic Review, 92, 874-888.

Scharfstein D., and Stein J., (2000), "The dark side of internal capital markets: divisional rent seeking and inefficient investment", Journal of Finance, 55(6): 2537-2564.

Stern, G., and R. Feldman (2009), "Too big to fail: The Hazards of bank bailouts," Brookings Institution Press, Washington, D.C.

Ueda, K. and B. W. Di Mauro (2013), "Quantifying structural subsidy values for systemically important financial institutions," Journal of Banking \& Finance 37 (10), 3830-3842. 
Table 1: Definition of variables and data source

\begin{tabular}{|c|c|c|c|}
\hline Variable & Formula & Definition and explanation & Data source \\
\hline \multicolumn{4}{|c|}{ Complexity measures of global banking organization } \\
\hline $\begin{array}{c}\text { Complexity } \\
\text { score }\end{array}$ & & $\begin{array}{l}\text { Complexity score published by BCBS } \\
\text { in assessing G-SIBs additional loss } \\
\text { absorbency requirement. }\end{array}$ & BCBS \\
\hline $\begin{array}{l}\text { Business } \\
\text { complexity }\end{array}$ & $\frac{T}{T-1}\left(1-\sum_{\tau=1}^{T}\left(\frac{\text { revenue }_{\tau}}{\text { total revenue }}\right)^{2}\right)$ & $\begin{array}{l}\text { The normalized Herfindahl index } \\
\text { has a value between } 0 \text { and } 1 \text {, with a } \\
\text { higher index value reflects a higher } \\
\text { degree of business complexity. } \\
\tau \text { is the distinct business type from } \\
\text { which the global banking } \\
\text { organization generates revenue in a } \\
\text { given year, where business types } \\
\text { are according to the North } \\
\text { American Industry Classification } \\
\text { System (NAICS). } \\
T \text { is the total number of distinct } \\
\text { business types from which the } \\
\text { global banking organization } \\
\text { generates revenue in a given year. } \\
\text { Commercial banking has a NAICS } \\
\text { code of } 522 \text {. Other business types } \\
\text { are defined according to 3-digit } \\
\text { NAICS codes for financial industries } \\
\text { and } 2 \text {-digit NAICS codes for all other } \\
\text { industries. }\end{array}$ & Capital IQ \\
\hline $\begin{array}{l}\text { Geographic } \\
\text { complexity }\end{array}$ & 1 -(domestic revenue / total revenue) & $\begin{array}{l}\text { The share of non-domestic revenue } \\
\text { in total revenue has a value } \\
\text { between } 0 \text { and 1, with a higher } \\
\text { value reflects a higher degree of } \\
\text { geographic complexity. } \\
\text { Domestic revenue includes } \\
\text { revenues from the global banking } \\
\text { organization's home country. }\end{array}$ & Capital IQ \\
\hline $\begin{array}{c}\text { Scope } \\
\text { complexity }\end{array}$ & $\sum_{\tau=1}^{T}\left(\right.$ distance $_{\tau} \times$ revenue $\left._{\tau}\right) /$ total revenue & $\begin{array}{l}\text { The weighted average distance } \\
\text { from commercial banking has a } \\
\text { value between } 1 \text { and } 4 \text {, with a } \\
\text { higher value reflects a higher } \\
\text { degree of scope complexity. A } \\
\text { global bank that engages solely in } \\
\text { commercial banking activities has a } \\
\text { scope complexity equals } 1 \text {, whereas } \\
\text { an organization that engages solely } \\
\text { in nonfinancial activities has a } \\
\text { scope complexity of } 4 \text {. }\end{array}$ & Capital IQ \\
\hline
\end{tabular}




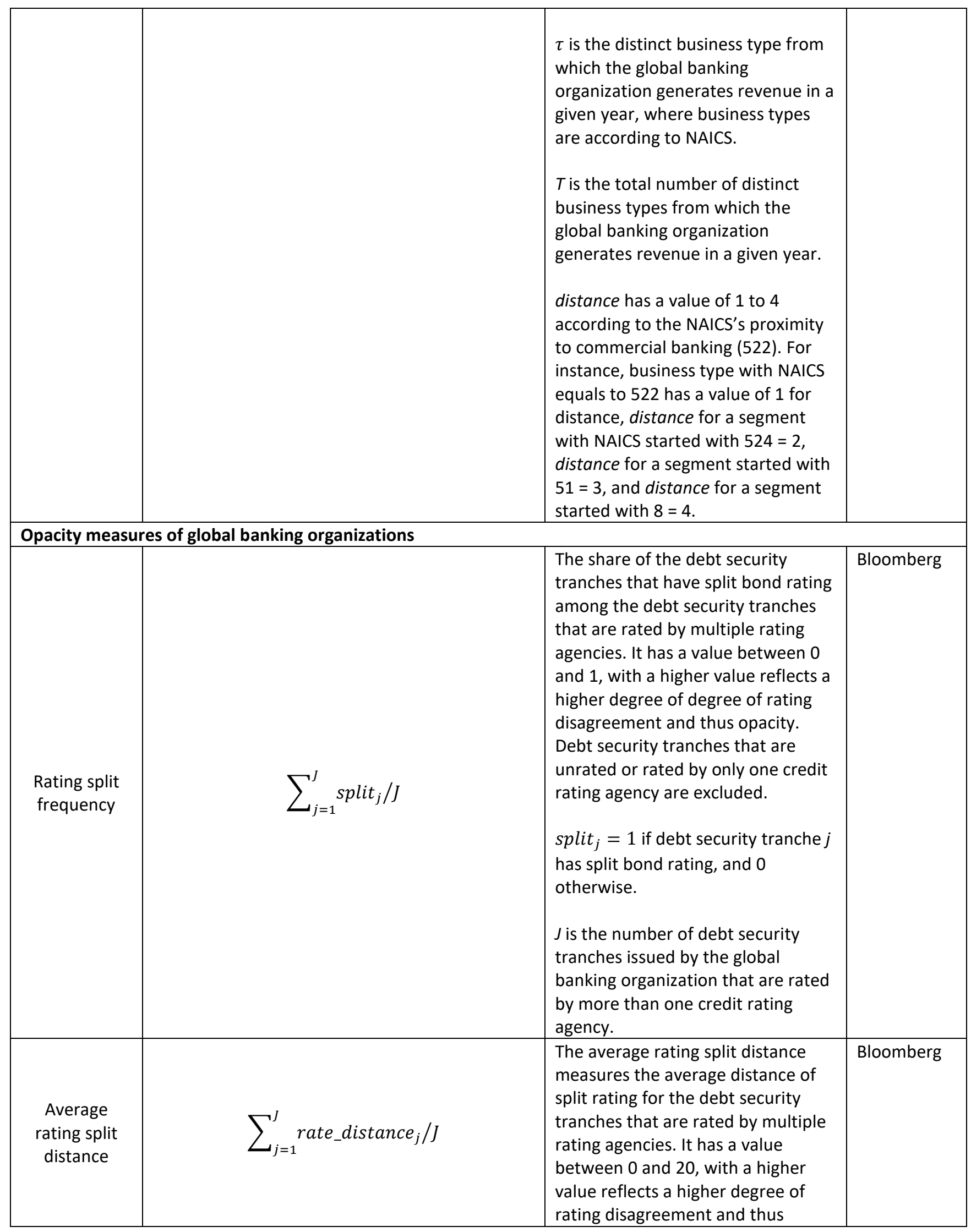




\begin{tabular}{|c|c|c|c|}
\hline & & 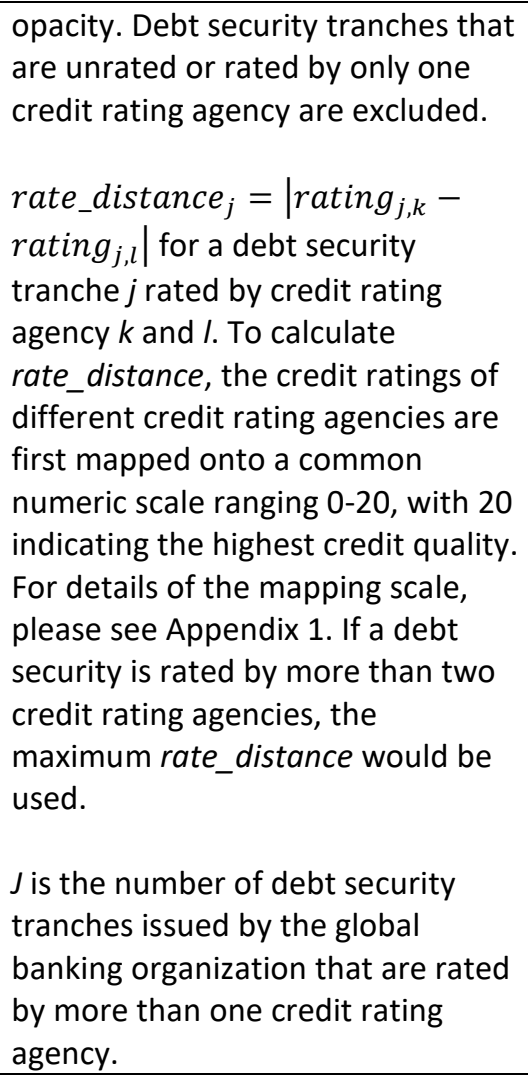 & \\
\hline Forecast error & $\frac{\left(\begin{array}{c}\left|\operatorname{median}\left(e p s_{-1}^{f}\right)-e p s^{a}\right| \\
+\left|\operatorname{median}\left(e p s_{-4}^{f}\right)-e p s^{a}\right| \\
+\left|\operatorname{median}\left(e p s_{-7}^{f}\right)-e p s^{a}\right| \\
+\left|\operatorname{median}\left(e p s_{-10}^{f}\right)-e p s^{a}\right|\end{array}\right) / 4}{\text { price }}$ & $\begin{array}{l}\text { The 4-quarter average of analysts' } \\
\text { forecast error of earnings per share } \\
\text { (EPS) of the global banking } \\
\text { organization. It takes average of the } \\
\text { forecast errors of the median } \\
\text { analyst } 1,4,7 \text { and } 10 \text { months prior } \\
\text { the earnings announcement date } \\
\text { and scaled by the year-end stock } \\
\text { price. A higher value reflects larger } \\
\text { analyst forecast errors, indicating } \\
\text { that the firm is more complex and } \\
\text { difficult to evaluate or understand, } \\
\text { i.e. a higher degree of opacity. } \\
\text { median (eps } f \text { ) is the median } \\
\text { forecast of EPS } m \text { months prior to } \\
\text { earnings announcement date. } \\
\text { eps } a \text { is the actual EPS. } \\
\text { price is the year-end stock price. }\end{array}$ & Bloomberg \\
\hline $\begin{array}{c}\text { Forecast } \\
\text { dispersion }\end{array}$ & $\frac{\left(\begin{array}{c}\mathrm{SD}\left(e p s_{-1}^{f}\right)+\mathrm{SD}\left(e p s_{-4}^{f}\right) \\
+\mathrm{SD}\left(e p s_{-7}^{f}\right)+\operatorname{SD}\left(e p s_{-10}^{f}\right)\end{array}\right) / 4}{\text { price }}$ & $\begin{array}{l}\text { The 4-quarter average of standard } \\
\text { deviation of analysts' forecast of } \\
\text { EPS of the global banking } \\
\text { organization. It takes average of the } \\
\text { standard deviation of analysts' } \\
\text { forecasts } 1,4,7 \text { and } 10 \text { months }\end{array}$ & Bloomberg \\
\hline
\end{tabular}




\begin{tabular}{|c|c|c|c|}
\hline & & $\begin{array}{l}\text { prior the earnings announcement } \\
\text { date and scaled by the year-end } \\
\text { stock price. A higher value reflects } \\
\text { greater disagreement across } \\
\text { analysts, indicating that the firm is } \\
\text { more complex and difficult to } \\
\text { evaluate or understand, i.e. a } \\
\text { higher degree of opacity. } \\
\mathrm{SD}\left(e p s_{-m}^{f}\right) \text { is the standard } \\
\text { deviation of forecasts } m \text { months } \\
\text { prior to earnings announcement } \\
\text { date. } \\
\text { eps }{ }^{a} \text { is the actual EPS. } \\
\text { price is the year-end stock price. }\end{array}$ & \\
\hline \multicolumn{4}{|c|}{ Business model variables of FBOs in Hong Kong } \\
\hline $\begin{array}{l}\text { Noninterest } \\
\text { income to } \\
\text { total income }\end{array}$ & non-interest income / total income & $\begin{array}{l}\text { The share of non-interest income in } \\
\text { total income of FBO in the year. It } \\
\text { measures the share of fee-based } \\
\text { activities contributing to total } \\
\text { revenues. }\end{array}$ & HKMA \\
\hline $\begin{array}{l}\text { Total loans to } \\
\text { total assets }\end{array}$ & total loans and advances / total assets & $\begin{array}{l}\text { The share of total loans in total } \\
\text { assets of FBO at the end of the } \\
\text { year. It measures the degree of } \\
\text { credit intermediation provided by } \\
\text { the FBO. }\end{array}$ & HKMA \\
\hline $\begin{array}{l}\text { Operating } \\
\text { cost to total } \\
\text { income }\end{array}$ & operating expenses / total income & $\begin{array}{l}\text { The cost-to-income ratio of FBO in } \\
\text { the year. A higher value reflects } \\
\text { lower cost efficiency. } \\
\text { operating expenses = } \\
\text { staff and rental expenses + other } \\
\text { expenses }\end{array}$ & HKMA \\
\hline $\begin{array}{l}\text { 4Q Average } \\
\text { funding cost }\end{array}$ & $\sum_{q=1}^{4}$ funding $\operatorname{cost}_{q} / 4$ & $\begin{array}{l}\text { The 4-quarter average Hong Kong } \\
\text { dollar and US dollar funding cost of } \\
\text { FBO in the year. Funding } \\
\text { denominated in these two } \\
\text { currencies accounts for nearly } 90 \% \\
\text { of the total liabilities at the end of } \\
2017 . \\
\text { funding cost is computed as the } \\
\text { weighted average of interest } \\
\text { expenses divided by total liabilities } \\
\text { for Hong Kong dollar and US dollar } \\
\text { denominated liabilities. } \\
q \text { is to the quarter in the year. }\end{array}$ & HKMA \\
\hline $\begin{array}{l}\text { Deposits to } \\
\text { assets }\end{array}$ & total deposits from customers / total assets & $\begin{array}{l}\text { The deposit-to-asset ratio of FBO at } \\
\text { the end of the year. It measures the }\end{array}$ & HKMA \\
\hline
\end{tabular}




\begin{tabular}{|c|c|c|c|}
\hline & & $\begin{array}{l}\text { share of FBO's assets that is funded } \\
\text { by deposits }\end{array}$ & \\
\hline $\begin{array}{l}\text { Wholesale } \\
\text { deposits to } \\
\text { assets }\end{array}$ & due to banks / total assets & $\begin{array}{l}\text { The wholesale deposit-to-asset } \\
\text { ratio of FBO at the end of the year. } \\
\text { It measures the share of FBO's } \\
\text { assets that is funded by interbank } \\
\text { funding. }\end{array}$ & HKMA \\
\hline \multicolumn{4}{|c|}{ Liquidity measures of FBOs in Hong Kong } \\
\hline $\begin{array}{l}\text { Liquid assets } \\
\text { to assets }\end{array}$ & liquid assets / total assets & $\begin{array}{l}\text { The share of liquid assets in total } \\
\text { assets of FBO at the end of the } \\
\text { year. A higher value reflects a } \\
\text { better liquidity condition. } \\
\text { liquid assets = } \\
\text { cash + due from Exchange Fund + } \\
\text { government bills, notes and bonds }\end{array}$ & HKMA \\
\hline $\begin{array}{l}\text { Net due from } \\
\text { overseas } \\
\text { offices to } \\
\text { assets }\end{array}$ & net due from overseas offices / total assets & $\begin{array}{l}\text { The ratio of net due from overseas } \\
\text { offices to total assets of FBO at the } \\
\text { end of the year. A higher absolute } \\
\text { value reflects a higher degree of } \\
\text { connectedness with the FBO's } \\
\text { overseas offices. A positive value } \\
\text { indicates that the FBO is in the role } \\
\text { of a funding provider, where this } \\
\text { may in turn reflect a better liquidity } \\
\text { condition as the funding direction } \\
\text { could be reversed when needed. } \\
\text { net due from overseas offices = } \\
\text { due from overseas offices - due to } \\
\text { overseas offices }\end{array}$ & HKMA \\
\hline $\begin{array}{l}\text { Liquid assets } \\
\text { to runnable } \\
\text { debts }\end{array}$ & liquid assets / runnable debts & $\begin{array}{l}\text { The ratio of liquid assets to } \\
\text { runnable debt of FBO at the end of } \\
\text { the year. A higher value reflects a } \\
\text { better liquidity condition. } \\
\text { runnable debts = } \\
\text { demand deposits and current } \\
\text { accounts + savings deposits } \\
+ \text { time, call and notice deposits } \\
\text { (repayable or callable within } 7 \text { days) } \\
+ \text { amount payable under repos + } \\
\text { due to banks }\end{array}$ & HKMA \\
\hline $\begin{array}{l}\text { Net interbank } \\
\text { lending to } \\
\text { assets }\end{array}$ & net interbank lending / total assets & $\begin{array}{l}\text { The ratio of net interbank lending } \\
\text { to total assets. A higher value } \\
\text { reflects a higher degree of credit } \\
\text { intermediation provided by the FBO } \\
\text { in the interbank market, where this } \\
\text { could shed light on the FBOs' } \\
\text { interconnectedness with other } \\
\text { financial institutions in Hong Kong, }\end{array}$ & HKMA \\
\hline
\end{tabular}




\begin{tabular}{|c|c|c|c|}
\hline & & $\begin{array}{l}\text { as well as their potential spillover to } \\
\text { the host country financial system. } \\
\text { net interbank lending = } \\
\text { (due from banks - due from } \\
\text { connected Als in Hong Kong } \\
\text { - due from overseas offices) } \\
\text { - (due to banks - due to connected } \\
\text { Als in Hong Kong } \\
\text { - due to overseas office) }\end{array}$ & \\
\hline \multicolumn{4}{|c|}{ Risk measures of FBOs in Hong Kong } \\
\hline $\begin{array}{c}\text { Classified loan } \\
\text { ratio }\end{array}$ & classified loans / total loans and advances & $\begin{array}{l}\text { The share of classified loans in total } \\
\text { loans of FBO at the end of the year. } \\
\text { A higher value reflects a lower asset } \\
\text { quality. } \\
\text { Classified loans are those loans } \\
\text { graded as "sub-standard", } \\
\text { "doubtful" or "loss". }\end{array}$ & HKMA \\
\hline $\begin{array}{c}\text { Net charge off } \\
\text { ratio }\end{array}$ & net charge-off / total loans and advances & $\begin{array}{l}\text { The ratio of net charge-off in the } \\
\text { year to total loans at the end of the } \\
\text { year of FBO. A higher value reflects } \\
\text { a lower asset quality. }\end{array}$ & HKMA \\
\hline ROA & operating profit before tax / average assets & $\begin{array}{l}\text { The return on assets of FBO. } \\
\text { average assets refers to the } \\
\text { average of monthly total assets in } \\
\text { the year. }\end{array}$ & HKMA \\
\hline $8 Q \mathrm{SD}(\mathrm{ROA})$ & $\begin{array}{c}\text { Standard deviation of quarterly ROA in the } \\
\text { trailing } 8 \text { quarters }\end{array}$ & $\begin{array}{l}\text { The volatility of the return on assets } \\
\text { of FBO. A higher value reflects a } \\
\text { higher risk in FBO's performance. } \\
\text { Standard deviation of quarterly } \\
\text { ROA in the trailing } 8 \text { quarters. } \\
\text { Quarterly ROA figure is calculated } \\
\text { as the sum of operating profit } \\
\text { before tax of trailing } 4 \text { quarters } \\
\text { divided by the average total assets } \\
\text { in the trailing } 12 \text { months. }\end{array}$ & HKMA \\
\hline
\end{tabular}


Table 2: Descriptive statistics for 57 global banking organizations that have branch(es) in Hong Kong from 2013 to 2017.

\begin{tabular}{|c|c|c|c|c|c|c|c|}
\hline Panel A: Complexity \& opacity measures & Unit & $\mathrm{N}$ & mean & sd & p25 & p50 & p75 \\
\hline \multicolumn{8}{|c|}{\begin{tabular}{|l|l|} 
Complexity measures & \\
\end{tabular}} \\
\hline Complexity score & & 232 & 163.151 & 174.745 & 44.095 & 76.172 & 239.516 \\
\hline Business complexity & & 279 & 0.310 & 0.223 & 0.133 & 0.286 & 0.494 \\
\hline Geographic complexity & $\%$ & 260 & 35.173 & 23.705 & 14.325 & 35.469 & 51.065 \\
\hline Scope complexity & & 279 & 1.306 & 0.373 & 1.070 & 1.188 & 1.440 \\
\hline \multicolumn{8}{|l|}{ Opacity measures } \\
\hline Rating split frequency & decimal point & 236 & 0.898 & 0.206 & 0.889 & 1.000 & 1.000 \\
\hline Average rating split distance & & 236 & 1.920 & 0.841 & 1.236 & 2.000 & 2.500 \\
\hline Forecast error & $\%$ of stock price & 282 & 1.318 & 4.783 & 0.256 & 0.474 & 1.335 \\
\hline Forecast dispersion & $\%$ of stock price & 282 & 0.894 & 0.987 & 0.283 & 0.625 & 1.170 \\
\hline Panel B: FBO financial variables & Unit & $\mathrm{N}$ & mean & sd & p25 & p50 & $\mathrm{p} 75$ \\
\hline \multicolumn{8}{|l|}{ Business model } \\
\hline Noninterest income to total income & $\%$ & 252 & 39.849 & 28.228 & 16.384 & 33.361 & 59.795 \\
\hline Total loans to total assets & $\%$ & 275 & 28.160 & 18.448 & 15.164 & 29.807 & 40.625 \\
\hline Operating cost to total income & $\%$ & 256 & 63.210 & 34.731 & 30.661 & 63.918 & 84.879 \\
\hline $4 Q$ Average funding cost & $\%$ & 276 & 0.650 & 0.509 & 0.272 & 0.507 & 0.890 \\
\hline Deposits to assets & $\%$ & 275 & 26.982 & 22.882 & 7.339 & 24.070 & 38.280 \\
\hline Wholesale deposits to assets & $\%$ & 275 & 53.728 & 26.938 & 32.537 & 55.386 & 77.549 \\
\hline \multicolumn{8}{|l|}{ Liquidity management } \\
\hline Liquid assets to assets & $\%$ & 275 & 6.662 & 6.353 & 2.096 & 5.020 & 8.970 \\
\hline Net due from overseas offices to assets & $\%$ & 275 & -7.313 & 33.255 & -26.674 & -4.761 & 8.162 \\
\hline Liquid assets to runnable debt & $\%$ & 249 & 9.531 & 7.531 & 3.743 & 7.987 & 12.715 \\
\hline Net interbank lending to assets & $\%$ & 275 & -0.379 & 18.564 & -9.066 & 0.663 & 7.500 \\
\hline \multicolumn{8}{|l|}{ Risk taking and profitability } \\
\hline Classified loan ratio & $\%$ & 251 & 0.433 & 0.969 & 0.000 & 0.001 & 0.374 \\
\hline Net charge-off ratio & $\%$ & 241 & 0.170 & 0.341 & 0.000 & 0.015 & 0.184 \\
\hline ROA & $\%$ & 254 & 0.408 & 0.589 & 0.103 & 0.367 & 0.716 \\
\hline $8 Q \mathrm{SD}$ (ROA) & $\%$ & 246 & 0.477 & 0.634 & 0.127 & 0.245 & 0.501 \\
\hline
\end{tabular}


Table 3: Pearson's correlation coefficients between complexity \& opacity measures of $\mathbf{5 7}$ global banking organizations that have branch(es) in Hong Kong from 2013 to 2017.

\begin{tabular}{|c|c|c|c|c|c|c|c|c|}
\hline $\begin{array}{l}\text { Pairwise } \\
\text { correlation }\end{array}$ & $\begin{array}{c}\text { Complexity } \\
\text { score }\end{array}$ & $\begin{array}{l}\text { Business } \\
\text { complexity }\end{array}$ & $\begin{array}{l}\text { Geographic } \\
\text { complexity }\end{array}$ & $\begin{array}{c}\text { Scope } \\
\text { complexity }\end{array}$ & $\begin{array}{l}\text { Rating split } \\
\text { frequency }\end{array}$ & $\begin{array}{l}\text { Average } \\
\text { rating split } \\
\text { distance }\end{array}$ & $\begin{array}{c}\text { Forecast } \\
\text { error }\end{array}$ & $\begin{array}{c}\text { Forecast } \\
\text { dispersion }\end{array}$ \\
\hline $\begin{array}{l}\text { Complexity } \\
\text { score }\end{array}$ & 1 & & & & & & & \\
\hline $\begin{array}{l}\text { Business } \\
\text { complexity }\end{array}$ & $0.3208 * * *$ & 1 & & & & & & \\
\hline $\begin{array}{l}\text { Geographic } \\
\text { complexity }\end{array}$ & $0.2544 * * *$ & -0.0084 & 1 & & & & & \\
\hline $\begin{array}{l}\text { Scope } \\
\text { complexity }\end{array}$ & $0.3138 * * *$ & $0.4321 * * *$ & $0.2404 * * *$ & 1 & & & & \\
\hline $\begin{array}{l}\text { Rating split } \\
\text { frequency }\end{array}$ & -0.0043 & $-0.1132 *$ & $0.1523 * *$ & -0.0757 & 1 & & & \\
\hline $\begin{array}{l}\text { Average rating } \\
\text { split distance }\end{array}$ & $0.1409 * *$ & 0.0254 & $0.2208 * * *$ & 0.0378 & $0.6113 * * *$ & 1 & & \\
\hline Forecast error & 0.0301 & -0.0655 & $0.1251 * *$ & 0.019 & 0.0112 & 0.016 & 1 & \\
\hline $\begin{array}{l}\text { Forecast } \\
\text { dispersion }\end{array}$ & $0.1915^{* * *}$ & -0.0784 & $0.2845 * * *$ & $0.1433^{* *}$ & 0.0211 & 0.0388 & $0.5492 * * *$ & 1 \\
\hline
\end{tabular}

Note: $* * *, * *, *$ indicate significance at the $1 \%, 5 \%$ and $10 \%$ level respectively. 
Table 4: WLS regression results of FBOs business models on parent company's complexity

\begin{tabular}{|c|c|c|c|c|c|c|}
\hline & (1) & $(2)$ & (3) & (4) & (5) & (6) \\
\hline Dependent variable & $\begin{array}{l}\text { Noninterest } \\
\text { income to } \\
\text { total income }\end{array}$ & $\begin{array}{l}\text { Operating } \\
\text { cost to total } \\
\text { income }\end{array}$ & $\begin{array}{c}\text { Total loans to } \\
\text { total assets }\end{array}$ & $\begin{array}{c}\text { Deposits to } \\
\text { assets }\end{array}$ & $\begin{array}{c}\text { Wholesale } \\
\text { deposits to } \\
\text { assets }\end{array}$ & $\begin{array}{l}\text { 4Q Average } \\
\text { funding cost }\end{array}$ \\
\hline Complexity score & $\begin{array}{c}0.0511 * * * \\
(0.0118)\end{array}$ & $\begin{array}{c}0.0638 * * * \\
(0.0109)\end{array}$ & $\begin{array}{c}0.0150^{*} \\
(0.00770)\end{array}$ & $\begin{array}{c}0.0505 * * * \\
(0.00796)\end{array}$ & $\begin{array}{c}-0.0367 * * * \\
(0.0102)\end{array}$ & $\begin{array}{c}-0.000373 * * * \\
(0.000110)\end{array}$ \\
\hline Business complexity & $\begin{array}{c}4.706 \\
(9.200)\end{array}$ & $\begin{array}{l}-3.239 \\
(8.749)\end{array}$ & $\begin{array}{l}-0.820 \\
(5.066)\end{array}$ & $\begin{array}{l}0.0653 \\
(5.440)\end{array}$ & $\begin{array}{c}4.629 \\
(8.432)\end{array}$ & $\begin{array}{c}-0.371 * * * \\
(0.0986)\end{array}$ \\
\hline Geographic complexity & $\begin{array}{c}0.145 \\
(0.103)\end{array}$ & $\begin{array}{c}0.0129 \\
(0.0967)\end{array}$ & $\begin{array}{c}0.0984 * * \\
(0.0461)\end{array}$ & $\begin{array}{c}0.259 * * * \\
(0.0658)\end{array}$ & $\begin{array}{c}-0.100 \\
(0.0949)\end{array}$ & $\begin{array}{c}-0.00794 * * * \\
(0.00138)\end{array}$ \\
\hline Scope complexity & $\begin{array}{c}17.86 * * \\
(7.699) \\
\end{array}$ & $\begin{array}{c}14.76^{* *} \\
(6.229) \\
\end{array}$ & $\begin{array}{c}-9.925 * * * \\
(3.257)\end{array}$ & $\begin{array}{c}0.109 \\
(2.847) \\
\end{array}$ & $\begin{array}{c}2.653 \\
(4.476) \\
\end{array}$ & $\begin{array}{c}-0.100 \\
(0.0650)\end{array}$ \\
\hline Rating split frequency & $\begin{array}{l}17.62 * \\
(9.607)\end{array}$ & $\begin{array}{l}-11.75 \\
(9.940)\end{array}$ & $\begin{array}{c}-10.10 * \\
(5.876)\end{array}$ & $\begin{array}{c}-24.72 * * * \\
(7.621)\end{array}$ & $\begin{array}{l}27.18^{*} \\
(14.68)\end{array}$ & $\begin{array}{l}-0.182 \\
(0.125)\end{array}$ \\
\hline Average rating split distance & $\begin{array}{c}5.773 * * \\
(2.780) \\
\end{array}$ & $\begin{array}{c}13.11^{* * *} \\
(2.700)\end{array}$ & $\begin{array}{c}-6.052 * * * \\
(1.678)\end{array}$ & $\begin{array}{c}4.083^{* *} \\
(1.949) \\
\end{array}$ & $\begin{array}{c}-11.34 * * * \\
(3.171)\end{array}$ & $\begin{array}{c}0.0444 \\
(0.0373) \\
\end{array}$ \\
\hline Forecast error & $\begin{array}{c}1.239 * * * \\
(0.383)\end{array}$ & $\begin{array}{c}0.984 * * * \\
(0.309)\end{array}$ & $\begin{array}{l}-0.172 \\
(0.205)\end{array}$ & $\begin{array}{c}0.246 \\
(0.209)\end{array}$ & $\begin{array}{c}0.520 \\
(0.431)\end{array}$ & $\begin{array}{c}-0.0248 * * * \\
(0.00484)\end{array}$ \\
\hline Forecast dispersion & $\begin{array}{c}-8.854 * * \\
(4.240) \\
\end{array}$ & $\begin{array}{c}-10.80 * * * \\
(3.369)\end{array}$ & $\begin{array}{l}-2.238 \\
(2.409) \\
\end{array}$ & $\begin{array}{c}-8.468 * * * \\
(2.162) \\
\end{array}$ & $\begin{array}{l}-2.634 \\
(4.893) \\
\end{array}$ & $\begin{array}{c}0.307^{* * *} \\
(0.0508)\end{array}$ \\
\hline Regulation tightness & $\begin{array}{c}-3.052 * * \\
(1.297) \\
\end{array}$ & $\begin{array}{c}-5.243^{* * *} \\
(1.286) \\
\end{array}$ & $\begin{array}{c}-5.434 * * * \\
(0.792)\end{array}$ & $\begin{array}{c}-3.141 * * * \\
(0.810)\end{array}$ & $\begin{array}{l}-1.786 \\
(1.654) \\
\end{array}$ & $\begin{array}{c}0.0426 * * * \\
(0.0161)\end{array}$ \\
\hline Multiple branches & $\begin{array}{c}0.171 \\
(3.099) \\
\end{array}$ & $\begin{array}{c}23.92^{* * *} \\
(4.281) \\
\end{array}$ & $\begin{array}{c}2.971 \\
(2.371) \\
\end{array}$ & $\begin{array}{c}1.235 \\
(2.547) \\
\end{array}$ & $\begin{array}{c}6.507 \\
(4.452) \\
\end{array}$ & $\begin{array}{l}-0.0795 \\
(0.0503) \\
\end{array}$ \\
\hline 2014.year & $\begin{array}{c}2.239 \\
(4.926)\end{array}$ & $\begin{array}{c}2.039 \\
(6.452)\end{array}$ & $\begin{array}{c}0.828 \\
(3.557)\end{array}$ & $\begin{array}{l}-0.688 \\
(3.742)\end{array}$ & $\begin{array}{l}-0.953 \\
(5.780)\end{array}$ & $\begin{array}{l}-0.0466 \\
(0.0685)\end{array}$ \\
\hline 2015.year & $\begin{array}{c}0.981 \\
(4.544)\end{array}$ & $\begin{array}{c}0.274 \\
(5.812)\end{array}$ & $\begin{array}{c}2.412 \\
(3.455)\end{array}$ & $\begin{array}{c}3.444 \\
(3.114)\end{array}$ & $\begin{array}{l}-8.393 \\
(5.127)\end{array}$ & $\begin{array}{c}0.0533 \\
(0.0523)\end{array}$ \\
\hline 2016.year & $\begin{array}{c}3.936 \\
(5.483)\end{array}$ & $\begin{array}{c}2.934 \\
(5.857)\end{array}$ & $\begin{array}{c}1.516 \\
(3.428)\end{array}$ & $\begin{array}{c}5.807 \\
(4.089)\end{array}$ & $\begin{array}{c}-13.24 * * \\
(6.084)\end{array}$ & $\begin{array}{c}0.263^{* * * *} \\
(0.0600)\end{array}$ \\
\hline 2017.year & $\begin{array}{l}-2.753 \\
(4.970)\end{array}$ & $\begin{array}{c}0.948 \\
(6.312)\end{array}$ & $\begin{array}{c}2.260 \\
(3.890)\end{array}$ & $\begin{array}{c}2.620 \\
(3.581)\end{array}$ & $\begin{array}{l}-8.866 \\
(6.297)\end{array}$ & $\begin{array}{c}0.739 * * * \\
(0.0682)\end{array}$ \\
\hline Constant & $\begin{array}{l}-16.12 \\
(13.55)\end{array}$ & $\begin{array}{c}34.77^{* *} \\
(14.88)\end{array}$ & $\begin{array}{c}81.65^{* * *} \\
(7.331)\end{array}$ & $\begin{array}{c}39.30 * * * \\
(9.430)\end{array}$ & $\begin{array}{c}71.24 * * * \\
(16.50)\end{array}$ & $\begin{array}{c}0.702 * * * \\
(0.151)\end{array}$ \\
\hline $\begin{array}{l}\text { Observations } \\
\text { R-squared }\end{array}$ & $\begin{array}{c}169 \\
0.566\end{array}$ & $\begin{array}{c}171 \\
0.573\end{array}$ & $\begin{array}{c}181 \\
0.436\end{array}$ & $\begin{array}{c}181 \\
0.560\end{array}$ & $\begin{array}{c}181 \\
0.353\end{array}$ & $\begin{array}{c}181 \\
0.760\end{array}$ \\
\hline
\end{tabular}

\section{Notes:}

1. Robust standard errors are in parenthesis. $* * *, * *, *$ indicate significance at the $1 \%, 5 \%$ and $10 \%$ level respectively.

2. For the variable of regulation tightness, the index of "Overall Restrictions on Banking Activities" from BCL (2013) is used. A time-invariant value based on the 2011 survey is assigned to each home country, except Germany, Japan and Sweden. The three countries have a missing value for this index in the 2011 survey, thus the value of 2007 survey is used instead. 
Table 5: WLS regressions of FBOs liquidity management on parent company's complexity

\begin{tabular}{|c|c|c|c|c|}
\hline & (1) & $(2)$ & (3) & (4) \\
\hline Dependent variable & $\begin{array}{c}\text { Net due from } \\
\text { overseas offices to } \\
\text { assets }\end{array}$ & $\begin{array}{c}\text { Liquid assets to } \\
\text { assets }\end{array}$ & $\begin{array}{c}\text { Liquid assets to } \\
\text { runnable debt }\end{array}$ & $\begin{array}{c}\text { Net interbank } \\
\text { lending to assets }\end{array}$ \\
\hline Complexity score & $\begin{array}{l}-0.00616 \\
(0.00936)\end{array}$ & $\begin{array}{c}0.00815 * * * \\
(0.00246)\end{array}$ & $\begin{array}{c}0.00867 * * \\
(0.00352)\end{array}$ & $\begin{array}{c}0.0153 * * * \\
(0.00487)\end{array}$ \\
\hline Business complexity & $\begin{array}{c}10.50 \\
(7.290)\end{array}$ & $\begin{array}{c}1.656 \\
(1.696)\end{array}$ & $\begin{array}{c}4.563 \\
(2.848)\end{array}$ & $\begin{array}{c}-16.71 * * * \\
(4.439)\end{array}$ \\
\hline Geographic complexity & $\begin{array}{c}0.0925 \\
(0.0872)\end{array}$ & $\begin{array}{c}0.113^{* * *} \\
(0.0209)\end{array}$ & $\begin{array}{c}0.161 * * * \\
(0.0313)\end{array}$ & $\begin{array}{l}-0.0420 \\
(0.0394)\end{array}$ \\
\hline Scope complexity & $\begin{array}{c}1.430 \\
(4.656)\end{array}$ & $\begin{array}{c}-3.418 * * * \\
(0.834)\end{array}$ & $\begin{array}{c}-3.314^{* *} \\
(1.281)\end{array}$ & $\begin{array}{c}7.818^{* * *} \\
(2.929)\end{array}$ \\
\hline Rating split frequency & $\begin{array}{c}0.825 \\
(12.96)\end{array}$ & $\begin{array}{c}0.284 \\
(1.906)\end{array}$ & $\begin{array}{l}-1.105 \\
(3.675)\end{array}$ & $\begin{array}{c}0.293 \\
(4.473)\end{array}$ \\
\hline Average rating split distance & $\begin{array}{l}7.644 * * \\
(3.066)\end{array}$ & $\begin{array}{c}0.140 \\
(0.638)\end{array}$ & $\begin{array}{c}0.480 \\
(0.869)\end{array}$ & $\begin{array}{c}0.627 \\
(1.381)\end{array}$ \\
\hline Forecast error & $\begin{array}{l}-0.766 \\
(0.467)\end{array}$ & $\begin{array}{c}0.151^{*} \\
(0.0822)\end{array}$ & $\begin{array}{c}0.161 \\
(0.110)\end{array}$ & $\begin{array}{c}0.431 * * \\
(0.194)\end{array}$ \\
\hline Forecast dispersion & $\begin{array}{l}9.367^{*} \\
(5.545)\end{array}$ & $\begin{array}{l}-1.234 \\
(0.875)\end{array}$ & $\begin{array}{l}-1.070 \\
(1.192)\end{array}$ & $\begin{array}{c}-4.903 * * * \\
(1.821)\end{array}$ \\
\hline Regulation tightness & $\begin{array}{c}7.333^{* * *} \\
(1.620)\end{array}$ & $\begin{array}{l}-0.164 \\
(0.292)\end{array}$ & $\begin{array}{c}0.514 \\
(0.460)\end{array}$ & $\begin{array}{l}-0.382 \\
(0.480)\end{array}$ \\
\hline Multiple branches & $\begin{array}{c}-10.20 * * \\
(4.560)\end{array}$ & $\begin{array}{c}1.333 \\
(0.823)\end{array}$ & $\begin{array}{l}2.532 * * \\
(1.222)\end{array}$ & $\begin{array}{c}0.998 \\
(1.782)\end{array}$ \\
\hline 2014.year & $\begin{array}{c}5.264 \\
(5.609)\end{array}$ & $\begin{array}{c}0.586 \\
(1.435)\end{array}$ & $\begin{array}{c}2.220 \\
(1.689)\end{array}$ & $\begin{array}{l}-3.437 \\
(3.329)\end{array}$ \\
\hline 2015.year & $\begin{array}{c}17.11^{* * *} \\
(4.779)\end{array}$ & $\begin{array}{c}0.185 \\
(1.281)\end{array}$ & $\begin{array}{c}1.621 \\
(1.510)\end{array}$ & $\begin{array}{c}-8.724 * * * \\
(3.191)\end{array}$ \\
\hline 2016.year & $\begin{array}{c}18.78^{* * *} \\
(5.544)\end{array}$ & $\begin{array}{c}0.998 \\
(1.284)\end{array}$ & $\begin{array}{c}3.606 * * \\
(1.635)\end{array}$ & $\begin{array}{c}-6.348 * * \\
(3.134)\end{array}$ \\
\hline 2017.year & $\begin{array}{c}14.58^{* *} \\
(6.399)\end{array}$ & $\begin{array}{c}0.311 \\
(1.251)\end{array}$ & $\begin{array}{c}1.822 \\
(1.596)\end{array}$ & $\begin{array}{l}-5.454^{*} \\
(3.107)\end{array}$ \\
\hline Constant & $\begin{array}{c}-74.82 * * * \\
(14.65)\end{array}$ & $\begin{array}{c}6.097 * * \\
(2.768)\end{array}$ & $\begin{array}{c}1.553 \\
(4.935)\end{array}$ & $\begin{array}{c}0.361 \\
(5.867)\end{array}$ \\
\hline $\begin{array}{l}\text { Observations } \\
\text { R-squared }\end{array}$ & $\begin{array}{c}181 \\
0.343\end{array}$ & $\begin{array}{c}181 \\
0.475\end{array}$ & $\begin{array}{c}159 \\
0.474\end{array}$ & $\begin{array}{c}181 \\
0.196\end{array}$ \\
\hline
\end{tabular}

\section{Notes:}

1. Robust standard errors are in parenthesis. $* * *, * *, *$ indicate significance at the $1 \%, 5 \%$ and $10 \%$ level respectively.

2. For the variable of regulation tightness, the index of "Overall Restrictions on Banking Activities" from BCL (2013) is used. A time-invariant value based on the 2011 survey is assigned to each home country, except Germany, Japan and Sweden. The three countries have a missing value for this index in the 2011 survey, thus the value of 2007 survey is used instead. 
Table 6: WLS regressions of FBOs risk and profitability on parent company's complexity

\begin{tabular}{|c|c|c|c|c|}
\hline & (1) & (2) & (3) & (4) \\
\hline Dependent variable & Classified loan ratio & Net charge-off ratio & ROA & 8Q SD (ROA) \\
\hline Complexity score & $\begin{array}{c}0.000717 \\
(0.000609)\end{array}$ & $\begin{array}{c}-6.11 e-05 \\
(0.000135)\end{array}$ & $\begin{array}{c}-0.000495^{* *} \\
(0.000204)\end{array}$ & $\begin{array}{l}0.000384 * \\
(0.000194)\end{array}$ \\
\hline Business complexity & $\begin{array}{c}0.973 * * \\
(0.420)\end{array}$ & $\begin{array}{c}0.103 \\
(0.124)\end{array}$ & $\begin{array}{l}0.0571 \\
(0.163)\end{array}$ & $\begin{array}{c}-0.256^{* *} \\
(0.129)\end{array}$ \\
\hline Geographic complexity & $\begin{array}{l}0.0127 * * \\
(0.00519)\end{array}$ & $\begin{array}{c}9.61 \mathrm{e}-05 \\
(0.00149)\end{array}$ & $\begin{array}{c}0.00448 * * \\
(0.00175)\end{array}$ & $\begin{array}{r}-0.000841 \\
(0.00155)\end{array}$ \\
\hline Scope complexity & $\begin{array}{c}-0.469 * * \\
(0.192)\end{array}$ & $\begin{array}{c}-0.113^{* * *} \\
(0.0421)\end{array}$ & $\begin{array}{l}0.0396 \\
(0.122) \\
\end{array}$ & $\begin{array}{c}0.0334 \\
(0.0946)\end{array}$ \\
\hline $\begin{array}{l}\text { Rating split frequency } \\
\text { Average rating split distance }\end{array}$ & $\begin{array}{c}0.577 \\
(0.430) \\
-0.00973 \\
(0.117) \\
\end{array}$ & $\begin{array}{c}-0.00383 \\
(0.129) \\
0.00386 \\
(0.0390) \\
\end{array}$ & $\begin{array}{c}0.193 \\
(0.133) \\
-0.0994^{*} \\
(0.0544) \\
\end{array}$ & $\begin{array}{c}-0.483^{* *} \\
(0.211) \\
0.146 * * \\
(0.0621) \\
\end{array}$ \\
\hline $\begin{array}{l}\text { Forecast error } \\
\text { Forecast dispersion }\end{array}$ & $\begin{array}{c}-0.00386 \\
(0.0173) \\
0.156 \\
(0.180) \\
\end{array}$ & $\begin{array}{c}-0.000931 \\
(0.00557) \\
0.0592 \\
(0.0561) \\
\end{array}$ & $\begin{array}{c}-0.00284 \\
(0.00622) \\
-0.00181 \\
(0.0621) \\
\end{array}$ & $\begin{array}{c}-0.0131 \\
(0.00823) \\
0.149 * \\
(0.0858) \\
\end{array}$ \\
\hline Regulation tightness & $\begin{array}{c}0.150 * * * \\
(0.0535)\end{array}$ & $\begin{array}{l}0.00796 \\
(0.0161)\end{array}$ & $\begin{array}{r}-0.00594 \\
(0.0294) \\
\end{array}$ & $\begin{array}{c}-0.105^{* * *} \\
(0.0324)\end{array}$ \\
\hline Multiple branches & $\begin{array}{l}-0.344^{*} \\
(0.174)\end{array}$ & $\begin{array}{c}0.0262 \\
(0.0537)\end{array}$ & $\begin{array}{c}-0.195 * * * \\
(0.0656)\end{array}$ & $\begin{array}{l}-0.168 * * \\
(0.0711)\end{array}$ \\
\hline 2014.year & $\begin{array}{l}-0.0189 \\
(0.318)\end{array}$ & $\begin{array}{c}-0.0984 * * \\
(0.0461)\end{array}$ & $\begin{array}{l}0.0496 \\
(0.105)\end{array}$ & $\begin{array}{l}-0.247 \\
(0.202)\end{array}$ \\
\hline 2015.year & $\begin{array}{c}-0.0320 \\
(0.276)\end{array}$ & $\begin{array}{l}-0.0893 \\
(0.0625)\end{array}$ & $\begin{array}{c}0.0758 \\
(0.0977)\end{array}$ & $\begin{array}{l}-0.279 \\
(0.174)\end{array}$ \\
\hline 2016.year & $\begin{array}{c}0.172 \\
(0.295)\end{array}$ & $\begin{array}{c}0.0340 \\
(0.0769)\end{array}$ & $\begin{array}{l}-0.0446 \\
(0.0895)\end{array}$ & $\begin{array}{c}-0.295 \\
(0.185)\end{array}$ \\
\hline 2017.year & $\begin{array}{l}-0.216 \\
(0.253)\end{array}$ & $\begin{array}{l}0.00592 \\
(0.0578)\end{array}$ & $\begin{array}{c}0.0188 \\
(0.0973)\end{array}$ & $\begin{array}{c}-0.293^{*} \\
(0.172)\end{array}$ \\
\hline Constant & $\begin{array}{l}-0.936 * \\
(0.496)\end{array}$ & $\begin{array}{c}0.164 \\
(0.187)\end{array}$ & $\begin{array}{c}0.333 \\
(0.277)\end{array}$ & $\begin{array}{c}1.098 * * * \\
(0.345)\end{array}$ \\
\hline $\begin{array}{l}\text { Observations } \\
\text { R-squared }\end{array}$ & $\begin{array}{c}167 \\
0.262\end{array}$ & $\begin{array}{c}163 \\
0.104\end{array}$ & $\begin{array}{c}162 \\
0.188\end{array}$ & $\begin{array}{c}162 \\
0.384\end{array}$ \\
\hline
\end{tabular}

Notes:

1. Robust standard errors are in parenthesis. $* * *, * *, *$ indicate significance at the $1 \%, 5 \%$ and $10 \%$ level respectively.

2. For the variable of regulation tightness, the index of "Overall Restrictions on Banking Activities" from $B C L$ (2013) is used. A time-invariant value based on the 2011 survey is assigned to each home country, except Germany, Japan and Sweden. The three countries have a missing value for this index in the 2011 survey, thus the value of 2007 survey is used instead. 
Appendix 1: Conversion of discreet credit ratings from different rating agencies into numerical scale

\begin{tabular}{|c|c|c|c|c|c|}
\hline & Fitch & Moody's & $S \& P$ & $\begin{array}{l}\text { Japan Credit } \\
\text { Rating agency, } \\
\text { Ltd. } \\
\text { (JCR) }\end{array}$ & $\begin{array}{l}\text { Rating \& } \\
\text { investment } \\
\text { information, } \\
\text { Inc. (R\&I) }\end{array}$ \\
\hline 20 & AAA & Aaa & AAA & AAA & AAA \\
\hline 19 & $\mathrm{AA}+$ & Aa1 & AAt & $A A+$ & $A A+$ \\
\hline 18 & $A A$ & Aa2 & AA & AA & AA \\
\hline 17 & AA- & Aa3 & AA- & AA- & AA- \\
\hline 16 & $A+$ & A1 & $A+$ & $A+$ & $A+$ \\
\hline 15 & $A$ & $\mathrm{~A} 2$ & $A$ & $A$ & $A$ \\
\hline 14 & A- & $\mathrm{A} 3$ & A- & A- & A- \\
\hline 13 & $\mathrm{BBB}+$ & Baa1 & $\mathrm{BBB}+$ & $\mathrm{BBB}+$ & $\mathrm{BBB}+$ \\
\hline 12 & BBB & Baa2 & BBB & BBB & BBB \\
\hline 11 & BBB- & Baa3 & BBB- & BBB- & BBB- \\
\hline 10 & $\mathrm{BB}+$ & Ba1 & $\mathrm{BB}+$ & $\mathrm{BB}+$ & $\mathrm{BB}+$ \\
\hline 9 & $\mathrm{BB}$ & $\mathrm{Ba} 2$ & BB & $\mathrm{BB}$ & $\mathrm{BB}$ \\
\hline 8 & BB- & $\mathrm{Ba} 3$ & BB- & BB- & BB- \\
\hline 7 & $\mathrm{~B}+$ & B1 & $\mathrm{B}+$ & $\mathrm{B}+$ & $\mathrm{B}+$ \\
\hline 6 & $\mathrm{~B}$ & B2 & $\mathrm{B}$ & $\mathrm{B}$ & $B$ \\
\hline 5 & B- & B3 & B- & B- & B- \\
\hline 4 & $\mathrm{CCC}$ & Caa1 & $\mathrm{CCC}+$ & $\mathrm{CCC}+$ & $\mathrm{CCC}+$ \\
\hline 3 & & Caa2 & $\mathrm{CCC}$ & $\mathrm{CCC}$ & $\mathrm{CCC}$ \\
\hline 2 & & Caa3 & CCC- & CCC- & CCC- \\
\hline 1 & & $\mathrm{Ca}$ & $\mathrm{CC} / \mathrm{C}$ & $\mathrm{CC} / \mathrm{C}$ & $\mathrm{CC} / \mathrm{C}$ \\
\hline 0 & $\mathrm{DDD} / \mathrm{DD} / \mathrm{D}$ & $C$ & $\mathrm{D}$ & $\mathrm{D}$ & $\mathrm{D}$ \\
\hline
\end{tabular}

